\title{
Modal verbs, future and grammaticalization in Old Catalan. A cognitive approach
}

\author{
Andreu Sentí \\ Universitat de València \\ andreu.senti@uv.es
}

Received: May 19, 2015

Accepted: June 17, 2015

\begin{abstract}
The process of grammaticalization of Catalan modal verbs deure, haver and tenir involves a semantic change, a rise of new meanings and an increase in their semantic network. On the one hand, deontic modal verbs develop inferential evidential meanings, and, on the other, future meanings (posteriority).

This corpus-based study focuses on the rise of future meanings of modal verb deure ('must') (between the $12^{\text {th }}$ and the $16^{\text {th }}$ centuries). We have been able to analyse the process of grammaticalization with absolute reliability thanks to the applied technology of the Corpus of Old Catalan (CICA and CIGCA), in which linguistic variation is quite representative. This study takes a cognitive perspective (Langacker 1987, 1991, 1999, 2006; Pelyvás 2000, 2006) that provides us with the tools to set up a semantic network and the paths of semantic change.
\end{abstract}

Keywords: modality; future; semantic change; Cognitive Grammar; grammaticalization; subjectification; conceptual schema.

Resum. Verbs modals, futur i gramaticalització en català antic: una aproximació cognitiva

La gramaticalització de les perífrasis verbals modals $<$ deure $+\mathrm{INF}>$, $<$ haver $($ a/de $)+\mathrm{INF}>\mathrm{i}<$ tenir $a / d e+\mathrm{INF}>$ va comportar una evolució semàntica i un procés de polisemització ric i complex. Les perífrasis d'obligació desenvolupen, per una banda, uns valors evidencials d'inferència $i$, per l'altra, uns valors de posterioritat temporal o futur.

Aquest estudi de corpus mostra el sorgiment $i$ evolució dels valors de futur de la perífrasi amb deure entre els segles XII-XVI. Amb les eines informàtiques d'un corpus del català antic (CICA i CIGCA) prou representatiu podrem observar el procés de gramaticalització amb la màxima fiabilitat possible. L'estudi pren una orientació cognitivista (Langacker 1987, 1991, 1999, 2006; Pelyvás 2000,2006 ) que ajudarà a configurar la xarxa semàntica de les perífrasis i els patrons de canvi semàntic que s'han produit.

Paraules clau: modalitat; futur; canvi semàntic; Gramàtica Cognitiva; gramaticalització; subjectivació; esquema conceptual. 


\section{Table of Contents}
1. Introduction
5. Future meaning of deure and the
2. Semantic connections between modality and future reconfiguration of the modal map in the $16^{\text {th }}$ century
3. Quantitative data
6. Conclusions
4. Emergence of future meanings of the modal verb deure

\section{Introduction}

In Old Catalan ( $11^{\text {th }}-16^{\text {th }} \mathrm{c}$.), modal verbal periphrasis $<$ deure + INF $>$ ('must') was the prototypical and the most frequent periphrasis to express deontic necessity (Sentí 2015). During the process of grammaticalization of the periphrasis, in the course of the $11^{\text {th }} \mathrm{c}$. and the $16^{\text {th }} \mathrm{c}$., new meanings appear and the semantic network of deure broadens significantly, following two grammaticalization patterns: i) NECESSITY $>$ INFERENTIAL EVIDENTIALITY ${ }^{1}$ and ii) NECESSITY $>$ FUTURE (Cabanes 1996, Martines in press, Schmid 2008). At the end of the Middle Ages, the semantic network of the periphrasis will have changed and the modality map in Catalan will be reconfigured. On the one hand, the new inferential evidential readings got to consolidate as a new semantic core of the periphrasis (Sentí 2015). On the other hand, with the grammaticalization and the appearance of the new future readings the category (deure) became more conventionalized, but this meaning did not settle and nowadays it is not one of the meanings of the verb in Modern Catalan. In this article we will focus on the latter case of frustrated grammaticalization. Due to the space reasons, we will not consider the development of inferential evidential readings (see Sentí 2015 for the analysis of the grammaticalization pattern NECESSITY $>$ INFERENTIAL EVIDENTIALITY).

In order to explain semantic change and evolution of deure we will apply Langacker's (1987, 1991) Cognitive Grammar (CG) framework. The framework proposed in these studies, as well as in further contributions (Langacker 1999, 2006; Pelyvás 2000, 2006) provides a convincing answer to two crucial semantic challenges: on the one hand, explaining the semantic network of the words (or constructions) and thus defining the phenomenon of polysemy and, on the other hand, explaining the semantic change. According to the $\mathrm{CG}$ framework, when the speaker/ground $(\mathrm{S} / \mathrm{G})$ wants to express a meaning and turns to a conventional schema, there can be a full sanction if this schema is conventionalised and entrenched. This is the case of the prototypical and more or less peripheral readings. In other cases, the schema may not go along with conventionality, which results in a partial sanction, that is, a change in the conceptual structure and, of course, a semantic change.

1. See Sentí and Cornillie (in press) for the account of inferential evidential meanings in connection with the epistemic modality. 
The periphrasis $<$ deure + INF $>$ in Old Catalan evolves and two more semantic cores emerge, a future reading and inferential evidentiality. The approach to the polysemy offered by the CG allows representing a semantic network of the semantic nuances and, at the same time, it allows putting together all the similar readings under a strong semantic core, or a prototypical reading that corresponds to the conceptual schema. As we will show, the evolution of the periphrasis reflects some modifications in the conceptual schema of the construction that incorporates force dynamics (Talmy 1988). The conceptual origin of necessity, the force, is gradually attenuating, which uncovers a subjective conceptualization of the scene.

This is a corpus study based on the corpora CICA and CIGCA, a balanced and representative corpus of Old Catalan with typologically different texts. In order to study deure we have analysed 2490 instances aiming to reach the highest precision in the study of Old Catalan. ${ }^{2}$ According to the corpus, in general, the periphrasis has a high frequency of use until the $15^{\text {th }} \mathrm{c}$. (between $0,08-0,1 \%$ ). In the $16^{\text {th }} \mathrm{c}$. though it decreases to $0,03 \%$. Indeed, it is in the $16^{\text {th }} \mathrm{c}$. when a change in modality and evidentiality occurs in Catalan. The grammaticalization of the periphrasis $<$ haver $($ alde $)+\mathrm{INF}^{3}$ replaces deure as a prototypical periphrasis of obligation (Sentí 2015), while a new semantic reading of deure, inferential evidentiality, becomes more widespread and the future reading retreats until it completely disappears. ${ }^{4}$ In this piece of research we will look at the origin and the evolution of future readings.

\section{Semantic connections between modality and future}

Modality and future are two concepts that, by definition, are very close. Modality is a linguistic category that modifies the status of the reality expressed in a sentence. That is, it lowers the validity of the sentence. ${ }^{5}$ Future, at the same time, is a hypothetical tense; it denotes something unknown and uncertain. A concept that covers both of these notions is that of irrealis. ${ }^{6}$

Such cognitive and semantic proximity explains why in Romance languages there are verbs, periphrases and constructions that are able to express both different modal meanings and future, or also meanings that are half way from the former to

2. However, corpus studies always have some methodological restrictions that are difficult to avoid (see Sentí 2013).

3. For a full diachronic study of the periphrasis the reader can refer to Sentí (2012).

4. See Sentí (2013) and Sentí and Antolí (2014) for a detailed quantitative analysis of semantic readings of the periphrasis and its evolution.

5. Given this perspective, one could include past and future tenses into such a vast category. Nevertheless, it is necessary to point out that, in general, the past and the future encode a state of affairs as a factual, regardless of it being real or not in the world. By contrast, modal category makes a reference precisely to an undetermined factual status (Narrog 2012: 6-7).

6. In fact, many typological studies have tried to analyse morphemes or markers that mark the difference between the real and the unreal (realis/irrealis). Some languages use specific irrealis morphemes to encode modality and future. However, this perspective also has some difficulties because irrealis is a very vast and ambiguous term. The reader can refer to de Haan (2006: 41-45, 50) for a state of the art. 
the latter. There is an amalgamation of meanings related to future or modality (cf. Martines in press). This is the case of modal verbs in romance languages and in Catalan, such as deure, haver and tenir. Besides, deontic modal meaning inherently entails a realisation that is posterior in time to the act of speech: every obligation is carried out afterwards.

A good example illustrating such connection is precisely the forming of Romance modal periphrases at the late stages of Vulgar Latin. Latin modal periphrases $<$ HABEŌ + INF $>,<$ DĒBEŌ + INF $>$ and $<\mathrm{UOLLO}+\mathrm{INF}^{7}$ appeared in colloquial speech and were gradually replacing Classical Latin forms that expressed modal meanings. Around the $3^{\text {rd }} \mathrm{c}$. AD some instances with future meaning had already been documented (Fleischman 1982). Without any doubt, it was the periphrasis featuring HABEŌ with a future meaning that became the most widespread over the Romance-speaking territories, probably because it was not loaded with that much of lexic and modal meaning when compared to the others, so that it ended up forming synthetic future (Future Simple) in modern Romance. However, the periphrases with DĒBEŌ and UŎLO were not a successful alternative to the classical forms that expressed future in Latin (Herman 2001: 86). Nevertheless, both of these periphrases entered Romance languages with a kind of future meaning manifested in some particular contexts. ${ }^{8}$

In ancient, preliterary Catalan texts we already find the modal verb deure with a future or posteriority meaning. As we will see, it is an underdeveloped meaning with modal nuances and it is bound to particular contexts only. In the course of the Medieval Period grammaticalization of the periphrasis continues and frequency of use of the verb with this reading increases. Thus, next to the transitional meanings, there will appear some new, more defined future meanings that will be distanced from modality.

\section{Quantitative data}

The prototypical meaning of the periphrasis with the verb deure, that of deontic necessity, and all the peripheral meanings of necessity represent the central core of the category. Inferential evidentiality develops and consolidates in the $16^{\text {th }} \mathrm{c}$. when it represents about $30 \%$ of the instances in the studied corpus (cf. Sentí 2015). Future meanings, by contrast, were present in Old Catalan from the very beginning. As the corpus shows, the development of the future meaning of the verb deure in Old Catalan follows a different path to that of the evidential meaning. In the period from the $11^{\text {th }} \mathrm{c}$. to 1350 posteriority meanings of deure already gain some significant presence, ${ }^{9}$ possibly because this meaning was already developed in Latin. The

7. Meyer-Lübke (1900, II: §112) makes a reference to them and shows six different ways to substitute the future: cantare habeo, habeo cantere, volo cantare, habeo ad cantare, debeo cantare, venio ad cantare.

8. In addition to the original deontic value, posteriority readings of $<\mathrm{DE} B E \bar{O}+\mathrm{INF}>$ were also documented in Romance languages.

9. It happens especially in the 13th c. (b) because in the chronicles (Fets) there are many situations of communication that allow for an inference of posteriority reading. 
Table 1. Core meanings of the periphrasis with deure in Old Catalan $\left(11^{\text {th }} \mathrm{c} .-16^{\text {th }} \mathrm{c}.\right)$

\begin{tabular}{lcccccc}
\hline & Preliterary & $13 b^{1}$ & $14 a$ & $14 b^{2}$ & 15 & 16 \\
\hline Necessity & $85,96 \%$ & $84,72 \%$ & $92,97 \%$ & $75,68 \%$ & $72,06 \%$ & $61,58 \%$ \\
\hline Evidentiality & $0,88 \%$ & $0,8 \%$ & $1,62 \%$ & $6,9 \%$ & $7,87 \%$ & $29,94 \%$ \\
\hline Future & $6,14 \%$ & $11,02 \%$ & $2,7 \%$ & $13,22 \%$ & $16,52 \%$ & $3,95 \%$ \\
\hline
\end{tabular}

1. In order to refer to the first half and the second half of a century we will use the letters $a$ and $b$ : $13^{\text {th }}$ c. (a) or $13^{\text {th }}$ c. (b).

2. We find it interesting to divide the $14^{\text {th }}$ century in two parts: the first half (14a) and the second half (14b). This grade of precision in the chronology allows pointing out a relevant evolution.

next stage (1350-1499) marks a kind of a turn: there is a considerable increase in frequency. Out of the total of instances, about $13-16 \%$ have a posteriority meaning. Such an increase shows an important settlement of the new meaning, although it is bound to particular communicative contexts, from which it does not distance enough. In the $16^{\text {th }} \mathrm{c}$. it becomes completely residual. The quantitative data are represented in the Table 1.

\section{Emergence of future meanings of the modal verb deure}

\subsection{Prototypical construction: deontic modality}

In Old Catalan the modal verbal periphrasis $<$ deure $+\mathrm{INF}>$ was the prototypical periphrasis to express deontic necessity (see Fig. 1, a construction represented within the Cognitive Grammar framework, Langacker 1987, 1991, 1999, 2006 and Pelyvas 2000, 2006). This reading forms an objective schema, in which the conceptual origin of modality is a force that comes from the imposer, a role that represents the locus of potency, that is, an external authority that is capable of sending out a force, an obligation. The imposer of the deontic modality is a moral, legal or social authority that can apply force to the doer, or the subject, the individual that has to carry out the proposed action, the state of affairs (SoA):

(1) car com una constitució és feta en cort, si·s publicha, se deu publicar tota ab integritat sens afegir-hi un mot ne tolre'n un altre (Safont, Dietari: 91, 14111484)

'As a constitution is made in cort (a government body), it must be published in its entirety, without adding any word or omitting another one'

The schema in the Figure 1 represents the prototypical reading of deontic necessity. The force, the arrow in bold, affects the subject or the doer, in order for him to carry out the action. The semi-oval line that links the subject of the verb deure (first circle of the doer) with the subject of the action or the infinitive (second circle of the doer) shows that it is the same participant.

The doer, the target of potency, in his turn, sends out a very weak counterforce that is represented as a crossed arrow. The obligation is so strong that it does not 


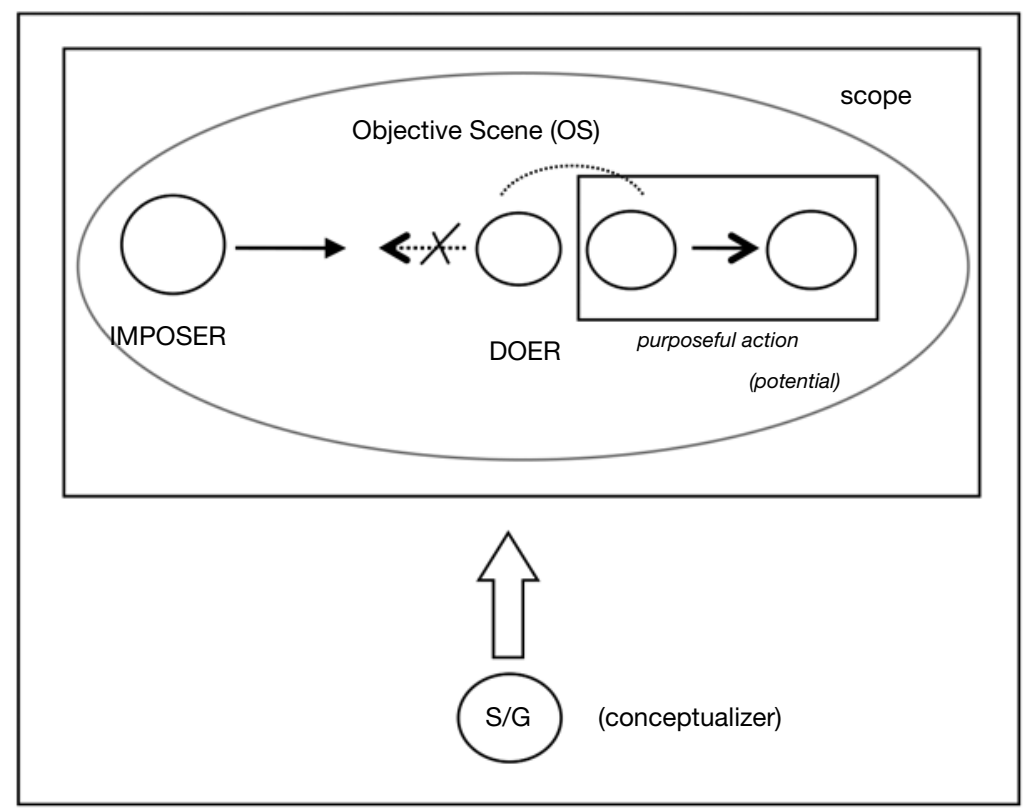

Figure 1. Conceptual schema of the prototypical deontic meaning of $<$ deure + INF $>$.

leave any possibility of not carrying out the potential action. In other words, the counterforce is not effective at all.

All the elements of the schema appear in the objective scene, which points out to all participants of the schema being prominent. The interaction of the forces, the modal relation and the SoA are focalized on the contents codified by the periphrasis $<$ deure $+\mathrm{INF}>$. However, the $\mathrm{S} / \mathrm{G}$ is not in the scene, he observes all the elements of the scene from the outside of the scope of predication. All in all, the construe of the schema is objective.

Next to the prototypical meaning of deontic necessity, there is a continuum of peripheral instances of deure that can be considered as elaborations of the prototypical conceptual schema (Fig. 1), such as external necessity (van der Auwera i Plungian 1998) or other more subjective readings with a slightly weakened force. For the reasons of space we do not describe them in this piece of research.

Among the above mentioned instances there is one type especially relevant to approach the future readings because it highlights the posteriority feature of the periphrasis. It is a meaning that can be found in administrative texts, in which the source of obligation is the current legislation. The legal authority makes a proposal of a law that can be interpreted as 'to be expected' or 'to be set'. With such a nuance, the schema presents an authority acting as the imposer that offers a project of the law, that gives some rights in the future. That is why the temporal schema is strengthened, but the necessity reading is still there. 
(2) La ja dicta Rumia demana per raon de sa maire; demana sa legítima e son dreit d'aquel dreit que sa maire avia ni aver devia en aquella honor de la serra subirana de Fígols (Medieval 31: 105, 1250-1255)

'Above mentioned Rumia asks for the reason of her mother; she asks for her legitimate inheritance and her (inherited) right that her mother had and she had to have for the sovereign land of Fígols'

\subsection{Transitional meanings towards posteriority}

Different studies on grammaticalization and semantic change have mentioned an intermediate stage in the process prior to achieving semantic change. At this stage there are some instances that can be attributed both to the original meaning and to the innovative meaning: indeterminate, ambiguous meanings, bridge contexts (Heine, Claudi and Hünnemeyer 1991). In what follows we consider those instances in corpus that admit a double interpretation. We will call them transitional uses (Goossens 2000) because they are located at the periphery of the prototypical meaning of necessity and at the same time, for some reason, they admit the inference of innovative meanings.

As we will show in what follows, all the meanings of transition from necessity towards future that the verb deure develops are related to the notion of planning. Attenuation of the locus of potency leads to the strengthening of the relation between the $\mathrm{S} / \mathrm{G}$ (who is a point of reference) and the SoA. That is to say, the obligation weakens and it becomes possible to interpret it as a plan, which is the origin of the innovative reading.

On the one hand, we find some transitional instances that are very similar to the above-mentioned peripheral value, 'to be set by the law' or 'to have the right to'. In such cases though the future meaning is more defined. The future interpretation is reinforced because any plan is carried out in posteriority to the act of communication.

(3) sí donams nós a vós czo que avems ni aver í devems per a[1]quna raó (Medieval 26: 97, 1241)

'thus I am giving to you what I have or will have for some reason'

We have documented five of ancient instances from Old Catalan, in which there is the same periphrastic structure featuring $<$ deure + haver-hi $>$. We have also found the same reading in Occitan (4) and Latin (5) texts. It is in the Occitan text where the linguistic context reinforces the future reading. In this instance the adverb adenant reveals the interpretation of posteriority.

(4) Eu Peire de Creissel et eu Uga, sa maire, dam et ab aquesta present carta liuram a te $[\ldots]$ tot quant nos avem ni adenant aver i devem $(P A C 1: 69,1151)$ 'I, Peire de Creissel, and I, Uga, his mother, are giving you and with this lletter we are giving you all that we have or will have from now on' 
(5) Totos meos directos quod ego habeo vel habere debeo (MiS-AnText: 20. 1176)

'All of my direct (relatives) that I have or will have'

As one can see, it is a repeated formula for official administrative texts and it is a part of a fixed formula that comes from Latin. It is important to remember that in that period Medieval Latin was by default the language of writing. In the end, it shows that the necessity reading is close to that of future, and that even in Latin it unfolded some future nuances. This is the beginning of a grammaticalization pattern that will further develop in Old Catalan.

On the other hand, we also find another type of periphrasis that can be interpreted as i) necessity (deontic or external) or ii) future scheduling. In these cases, there is an element in the context showing that the state of affairs will be carried out in the future, that it is planned. Modal meaning is still quite present but the planning (inherent to the future-oriented deontic modality) becomes more relevant. It often appears in the form of inchoative infinitives that indicate the beginning of some activity: fer batalla 'fight battle', entrar 'go in', passar 'pass', etc.:

(6) Los cavallers e $\cdot 1 \mathrm{~s}$ altres qui deven fer batalla deven ésser mesurats sots aquesta forma (Furs: vol. VIII, 54, 1261-1271)

'The knights and others that will fight the battle must be measured by this form'

(7) E enviam missatge la nuyt per los bisbes e per los richs hòmens que los dixés que al matí se devia fer açò (Fets: foli 84r)

'And I sent a message at night for the bishops and the rich people saying that in the morning this will have to be done'

(8) Per què us pregam affectuosament, si neguns temps nos devets servir, que, ab lo tresorer ensemps, nos acorregats ivaçosament d'alcuna bona quantitat ab què puxam arrencar la host (Pere IIIa: carta 1, 1343-1348)

'We beg you kindly, if you ever serve us, that you, together with the treasurer, pay us a good amount with the help of which we can start an army'

(9) Aprés que elles són bé farçides e plenes, entren-se'n en lurs cambres [...] e dormen entrò que deuen sopar (Metge, Somni: 220, 1398)

'After they are stuffed and full, they go to their rooms [...] and they sleep until they have to have supper'

(10) E la luna resta endret del meu cap e dels braços, senyalant lo camí que yo dech fer, e no és restada atràs ni al costat (Tirant: 1104, 1460)

'And the moon is above my head and arms, showing me the way I will have to make, and it is not behind me or on the side'

Another transitional meaning shows a little more clearly the proximity of such instances to the future meaning. 
(11) Per qé él s'aproxmave a la passió qe devie rede[bre] en Jherusalem (Homilies: 124$, c. 1200$)$

'Because he was approaching the passion that he was about to receive in Jerusalem'

(12) Qar així o trobam en la homelia de sent Gregori, qe u·monge fo e, qan se dec morir, devezí tot son aver e partí'l, estirs dos besans qe li oblidaren (Homilies: 122$, c. 1200$)$

'Because we find it in the homily of Saint Gregory, that there was a monk and, when he had to die, he divided all he had, except two besans that he forgot'

(13) en la festa de Sent Pere él devia preïcar als clerges (Vides: 439, 1275-1299) 'during Saint Peter's holiday he would preach to the clirics'

Here deure expresses a necessity different from the deontic one. The locus of potency of the necessity is not represented by a moral, legal or social imposer, but by future that is known for certain by everyone. For example, in (11) deure refers to something expected: everyone knows that the passion of Jesus Christ led to his death. Similarly, in (12) there are two periphrases in the same context: the S/G knows what the future is and he actually tells it in the same text: «estec-ne .XXX. dies en pena», that is, the monk died and went to hell. In the end, a narrative scene is generated, in which the $\mathrm{S} / \mathrm{G}$ already knows all the sequence of facts.

In the context of the past, deure expresses posteriority to a prior moment. Therefore, the role of the imposer (the necessity) weakens, and the reference to temporal posteriority of the periphrasis strengthens. The source of force is the encyclopedic knowledge of the $\mathrm{S} / \mathrm{G}$ who knows what happens in the future and who can say necessàriament deu morir, morirà ('he must inevitably die, he will die'). With these instances, the conformation of the conceptual schema has significantly changed, it is more subjective now. The process of grammaticalization of the periphrasis moves forward to more defined and more subjective meanings of posteriority or future.

Actually, the co-appearance of the verb deure with the infinitive morir 'to die' is not accidental because death is inevitable. Therefore, the developing of the new meaning of deure begins in a specific context, a narrative, in which from the present (C) one observes a point in the past (A) and a further moment (B) that is known and will surely occur, as shown in Fig. 2.

It is precisely the past context that lets us have the encyclopedic knowledge that makes sure the future prediction will be fulfilled: to some extent, it is a necessity.

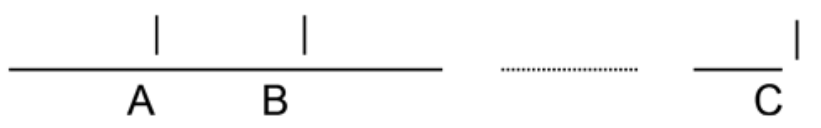

Figure 2. Narrative schema that allows the appearance of the posteriority meaning. 
Finally, there is another context, in which the verb deure has a future reading: some subjunctive mood clauses with the meaning of posteriority.

(14) lo papa consentí que dagués ésser amenat a la ciutat de Roma e que conegués quina fos la sua mesura (Diàlegs: foli 6r, 1250-1290)

'the Pope agreed that he will be led to the city of Rome and that he will know what its measurement is'

(15) no és dona ni donzella en lo món que de bon grat no·l degués amar e subjugarse a tota sa voluntat (Tirant: 483, 1460)

'there is no woman or maiden in the world who will not love him and obey him with all her determination'

All in all, some specific communnicative contexts are what encourages the beginning of the semantic change, allowing an interpretation of necessity different to the prototypical one: a legislative planification, some narrative contexts or subjunctive clauses. Such transitional meanings show a more general obligation and a conceptual schema with a weakened force that brings us closer to more defined future meanings, as we will see in the next section. All in all, they are links of the semantic chain that highlight the gradual character of semantic change.

\subsection{The future meaning of modal verb deure: scheduled future and imminent future}

\subsubsection{Scheduled future}

Alongside with the transitional meanings of the modal verb deure, we can also find contexts with a pure future meaning. The periphrasis consolidates a type of future that we have labeled scheduled future, and its frequency increases up to represent $16 \%$ of all instances of the periphrasis in the $15^{\text {th }} \mathrm{c}$. We have chosen the term scheduled because the posteriority in time expressed by it is always linked to a kind of schedule.

(16) devench molt gelós, e, encés de rabiosa ira, l'aguera mort en qualsevol partit, sinó pensant que dins breus dies la batalla se devia fer e aquella toldria la qüestió (Curial: 103, 1435-1445)

'He became very jealous and, ignited by anger, he would have killed him at any opportunity, but thinking that in a few days the battle had to happen, which would make the matter disappear'

In this example there is a force coming from a foresight or scheduling that anchors the SoA, que es fes la batalla 'that the battle had to happen', in the future.

The periphrases with this meaning do not sanction the prototypical conceptual schema of deontic necessity, there is rather a semantic extension. The interaction of forces has weakened and it reveals the future orientation of the construction that already was there. That is why the schema incorporates the timeline $(\mathrm{t})$. The locus of potency is modified: it is not the obligation anymore, it is the planning/ 


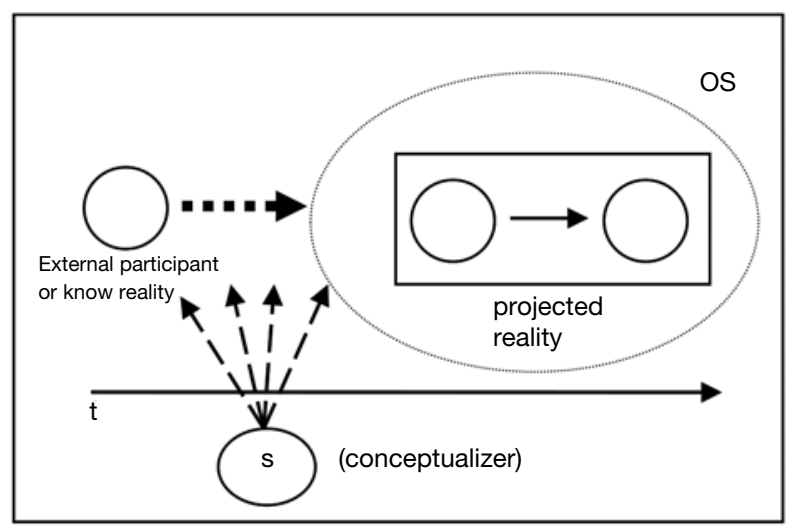

Figure 3. Conceptual schema of $<$ deure + INF $>$ with a scheduled future reading.

scheduling. Now the potency comes from some external to the SoA circumstances that project a future reality. In this regard, it is interesting to establish a link with Langacker's dynamic evolutionary model (1991a: 277) and the notion of projected reality, because here the $\mathrm{S} / \mathrm{G}$ conceptulizes a reality projected from the force of the path of the known reality.

The force has attenuated but it has not faded away completely. What remains of it is the planning because the illustrated meanings show that deure does not get a completely temporal conceptual schema with a completely temporal locus of potency. In other words, scheduled future can be viewed as a logical projection of the facts according to the speaker's encyclopedic knowledge (force).

As shown in the schema (Fig. 3), at this stage the relation of forces is still present but the agentive doer is not there anymore. The force applies directly to the whole SoA and not the doer, as it happened in the case of the necessity reading. Therefore, there is an objective scene (OS) with the SoA projected in the future. At this point, we are talking about an attenuation of the force and also of its target. In the end, the configuration is still objective because the locus of potency is still external to the $\mathrm{S} / \mathrm{G}$.

The periphrasis often co-occurs with infinitives denoting movement or change of state, such as venir 'come', anar 'go', metre 'put', entrar 'enter', morir 'die' that highlight the temporal schema. In many instances there are particles expressing time (see the underlined). There are instances dating back to the $13^{\text {th }} \mathrm{c}$. (b), even though their number increases in the period from 1350 to 1500 . That is why in the second half of the $14^{\text {th }} \mathrm{c}$. this conceptual schema can be considered as the new core meaning of the periphrasis.

(17) E, quan vench que fom segurs d'aquel estol que no devie venir de tot en tot, tornam-nos-en (Fets: foli 61v, XIIIb)

'And when we were sure that squadron was definitely not going to come, we went back' 
(18) Que com lo senyor rey a bon estament de la ciutat e del regne de València entena en breu de dies ésser en la dita ciutat e per aquesta rahó moltes honrades persones deuen venir a la dita ciutat (Manual I: 340, 1306-1324)

'Because His Majesty the King of the City and of Kingdom of Valencia will in some days be in this city, many honourable people will come to this city'

(19) Interrogatus si ere emprès entre ell testis deponens e lo dit P. Verger que la muller d'aquest testis degués morir. (Marquès: foli 20r, 1374-1477)

'When interrogated if they had decided who was to testify, the mentioned P. Verger said that the wife of that witness was to die'

(20) per lo matí, sabut per nosaltres que micer Francesch Blanch e micer Pere de Falchs, missatgers de aquesta ciutat a vós, senyor, trameses, devien entrar en aquella (Epistolari IIa: carta 115, 1412-1424)

'we know that Sir Francesch Blanch and Sir Pere de Falchs, messengers of this city, directed to you, Sir, will enter there in the morning'

(21) vigília de sent March, los consellers e altres buscaris de lur consell, volgueren fer cridar lo Consell de Cent Jurats per lo sendemà que devia ésser sent March (Safont, Dietari: 67, 1411-1484)

'on the eve of Saint Mark, the counsellors wanted to convene the Council of One Hundred Juries for the next day, that had to be the day of Saint Mark'

\subsubsection{Subjectification, grammaticalization and imminent future}

Finally, the periphrasis $<$ deure $+\mathrm{INF}>$ makes another step in grammaticalization and developing of future meanings: the meaning of imminent future ('to be about to do something') emerges. The conceptual schema presents a more subjective configuration and a major attenuation of the force. We have documented this meaning in some older texts already.

(22) E per ço cor no y avia loc ún se pogués posar, veu-la hom encare ara, qui garda al pug, penjar axí con si devia caur (Diàlegs: foli 2r, 1250-1290)

'And because of that, because there was no place where it could be placed, one can still see it, guarding the hill, as if it was going to fall'

(23) E, quan vench que·l sol se·n devia entrar, entraren-se'n los sarraïns (Fets: 167 r, s. XIIIb)

'And when the sun was to set, entered the Saracens'

(24) aquest testis víu qu'el dit A. jaheïa en i lit e gitava poderosament en i bací e, segons que paria, soferi[a] gran mal que semblave degués gitar los budels (Marquès: foli 25v, 1374-1377)

'This witness saw that A. was lying in bed and he was throwing up a lot into a bucket, and, as it seemed, he was so sick that he was about to throw up his guts' 
(25) Los seynals que signiffiquen pestilència ja present en l'àer són axí com terbolament en l'àer, car adés parrà que dege ploure e puixs no plou (Agramont: $59 \mathrm{~b}, 1348)$

'The signs of a plague present in the air are as a cloud in the air, as recently it seemed it was going to rain and it didn't rain'

The contexts of (22)-(25) do not admit any other interpretation apart from the imminent future. In (23) there is an inanimate subject, the sun, that makes the same cycle every day, so that everyone knows that it will set (entrarà). The infinitive of the periphrasis in (25) is an atmospheric (zerovalent) verb that does not fit into deontic modality. Actually, all of the four examples above have such a context that there cannot possibly be any obligation or intention of the participant: the sun, the rain, the gravity and being sick cannot be intentional.

The frequency of the periphrasis with this meaning increases considerably starting from 1350 , and especially in the $15^{\text {th }}$ century.

(26) Encontinent Orfeu callà, e jo, axí com aquell qui havia gran desig de hoir ço que dir-me devia, pregué'l instantment que·m volgués acabar ço que $m$ 'havia començat explicar dessús (Metge, Somni: 186, 1398)

'Then Orpheus became silent as the one who had a big desire to tell me what he was about to tell me, and I asked him then to finish what he had started telling me before'

(27) - Senyora, yo $\cdot \mathrm{m}$ pens que si aquesta donzella que ací és hagués sabut que vós la deguéssets retenir ací, e vós metre-us en companyia del cavaller per anar al torneig, crech que ab dur cor hi fóra venguda (Curial: 139, 1435-1445)

'Madam, I think that if this maiden that is now here knew that you would keep her here and to send her to the tournament accompanied by the knight, I think she would be reluctant to come'

(28) E fon tanta la remor que feren que paria que cel e terra ne degués venir (Tirant: 1383, 1460)

'And the noise that they made was such that it seemed that the sky and the ground would sink'

(29) E fonch-li imposat aquest cognom Tremolós per tal causa; ço és, que com devia entrar en batalla, ho havia a fer cavalcada (Carbonell, Cròniques: 245, 1495-1513)

'And so he was given the name of Tremolós for this reason: when he was about to go into a battle, he did so riding a horse'

Such meanings can sanction the conceptual schema of the scheduled future but with some nuances, as shown in Fig. 4.

In this schema there is a more subjective configuration because the modal relation has attenuated more and reveals the modal scanning of the conceptualiser 


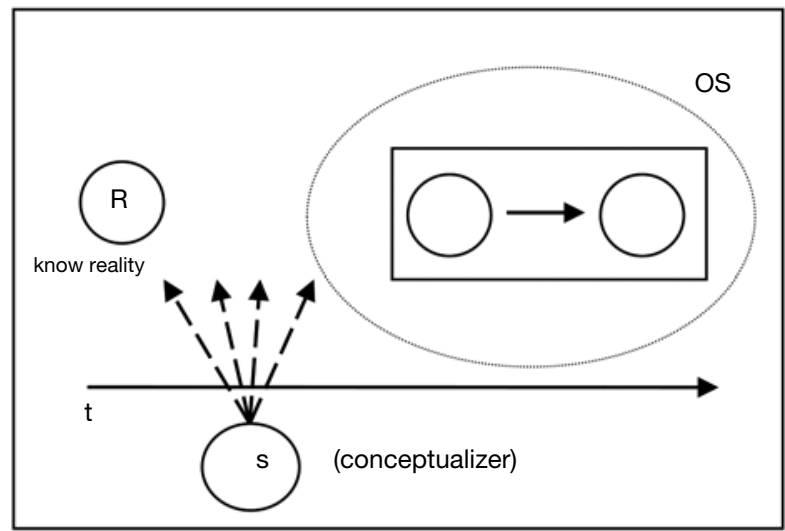

Figure 4. Conceptual schema of $<$ deure + INF $>$ with a more subjective future meaning.

(C); the verb deure refers to a known reality, it is related to the state of affairs. The (semi)-auxiliary is a point of reference (R), that is, an element subjectively related to the SoA because it gives all the spotlight to the projected reality, to the SoA that is in the objective scene (OS). A confirmation of the subjectification of the future meaning is the presence of hedges that point to the speaker's inference to the surrounding reality (see the underlined text: parrà, semblave, paria...).

This schema is different from that of the scheduled future because the external modal force (represented by the horizontal arrow in the Fig. 4) has faded away. By contrast, in cases of imminent future the locus of potency is attenuated: the force does not come from a known reality that allows planning, it is rather the inference that the speaker makes on what can happen judging by the reality he knows.

All in all, the periphrasis takes another step in grammaticalization and develops a more subjective meaning, in which the speaker's conceptualization is the locus of potency. After all, this stage is when major subjectification of the scene happens.

\subsubsection{Frustration of the grammaticalization}

Corpus data show that in the $16^{\text {th }} \mathrm{c}$. the future meaning that had been important during the previous centuries does not stay. However, as we know (Sentí 2015), deure consolidates another semantic core, the inferential evidential meaning. It is hard to say why this meaning does not stay while the process of grammaticalization makes a progress during the Middle Ages. Nevertheless, in what follows we suggest a possible reason for that. 


\section{Future meaning of deure and the reconfiguration of the modal map in the $16^{\text {th }}$ century}

Our hypothesis of the frustrated grammaticalization pattern NECESSITY $>$ FUTURE of the verb deure is based on two points. The first one refers to semantic characteristics of the periphrasis and the second one, to general reshaping of modal semantics of the periphrases that happens in the $16^{\text {th }}$ century.

With regard to the semantic reason, in this study we have been able to state that deure does not develop a completely subjective future meaning, that is, the conceptual schema does not completely attenuate the force. Although the S/G incorporates in the locus of potency of the more subjective conceptual schema of imminent future (Fig. 4), there is always a little bit of the objective force (in this case, inference of reality) that prevents the formation of a purely prospective schema. The persistence of the prototypical meaning prevents a major evolution (Traugott 2012). This could explain the fact that we do not find such meaning in the first person because the periphrasis cannot express intention, as we saw in the examples (23), (24) and (25). It is possible that the notion of planning (or of inference) interpreted as something remaining of the modal force still matters. In order to get to a pure future meaning, a greater subjectification process would have been needed, where the speaker could project his intention and attitude and where he could be free from external planifications and inferences. This is what the process of grammaticalization of those periphrases that follow such a pattern of semantic change is like, for example, analytical Romance periphrasis $\angle \mathrm{HABE} \overline{\mathrm{O}}$ + INF> (Bybee et al. 1994; Pérez-Saldanya 1998: 280-282), or Romance future periphrases featuring the verb anar 'to go'. However, deure does not follow this path. Although it does develop partially subjective future meanings, it does not achieve a complete subjectification.

The second reason is related to the reconfiguration of the modal map that happens in the $16^{\text {th }} \mathrm{c}$. On the one hand, in the $16^{\text {th }} \mathrm{c}$. the verb deure changes a lot (Sentí 2013, 2015): i) the frequency of its use decreases; ii) it gives up the role of the prototypical periphrasis of necessity and passes it to the periphrasis haver de; iii) it consolidates the evidential semantic core and iv) its future meanings become obsolete. On the other hand, the emergence of such periphrases of necessity as haver and tenir that gain frequency of use might be crucial. In the $16^{\text {th }} \mathrm{c}$. haver and tenir strengthen their future meanings (Sentí 2012). Everything points to these periphrases occupying the place of deure as a periphrasis with a (scheduled) future meaning.

As shown in the chart (Fig. 5), there is a reconfiguration in the modal map of Catalan in the $16^{\text {th }} \mathrm{c}$. when compared to the $15^{\text {th }} \mathrm{c}$.: the prototypical periphrasis to express necessity is not deure anymore, it is replaced by haver. At the same time, the periphrasis with haver takes over all the future readings that both periphrases had in the $15^{\text {th }} \mathrm{c}$. (in red).

In fact, the periphrasis with the verb haver develops the same readings of posteriority that we have analysed for deure and, if necessary, it gets to some more subjective structural conformations (Sentí 2012). Actually, in Modern Catalan, 


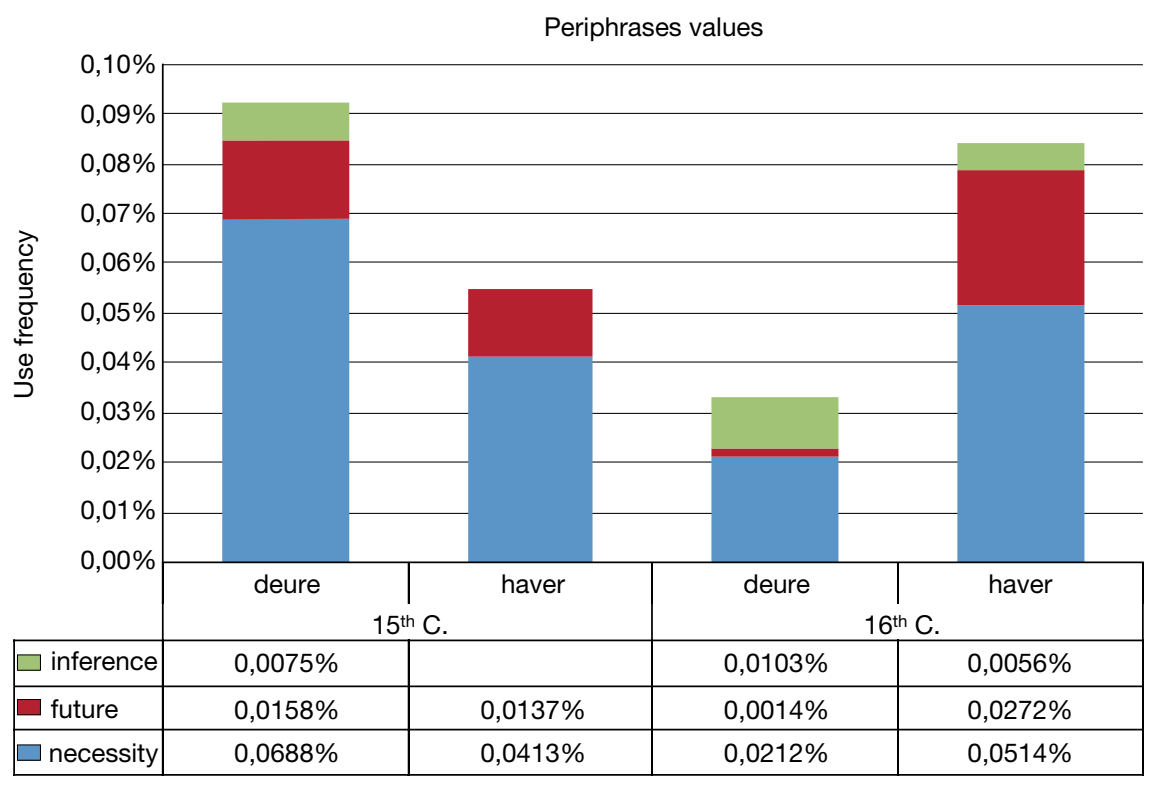

Figure 5. Necessity, future and inference readings in the $15^{\text {th }}$ and $16^{\text {th }}$ centuries. Frequency of use of deure and haver.

modal periphrasis with the verb haver may have a future reading. However, the one with the verb deure, cannot. ${ }^{10}$

(30) Havia de pujar a l'avió quan es va recordar de l'informe

'He was about to board when he remembered the report'

\section{Conclusions}

This corpus study shows that the periphrasis $<$ deure + INF $>$ goes through the process of grammaticalization during the Middle Ages. We have shown that this process brings with it some contextual demarcation and emergence of new readings that have a conceptual schema with a more subjective configuration (scheduled future and imminent future). There is a grammaticalization pattern

10. Indeed, in Modern Catalan, deure does not preserve this meaning. Future or Future in the Past is used instead, as well as the periphrasis $<$ haver de $+\mathrm{INF}>$ (Sentí 2012) or $<$ voler $+\mathrm{INF}>$ (Gavarró and Laca 2002: 2716). This semantic space has recently been invaded by the aspectual periphrasis <anar $a+\mathrm{INF}>$, which is the result of the influence of Spanish. In future studies it is important to look into the semantic distribution of the aspectual periphrases with the verbs haver and anar. 
NECESSITY > SCHEDULED FUTURE $>$ IMMINENT FUTURE, which unfolds gradually and has well-defined stages that contribute to the universal pattern of semantic change that had already been discovered (Bybee et al. 1994).

The number of instances of the verb deure with future meanings is representative and increasing up until 1500. Such instances illustrate a progressive attenuation of the source of conceptual force and uncover the temporal schema of the periphrasis, which causes semantic change. We have noticed that the increasing subjectification of the conceptual schema entails the emergence of new nuances that are more distanced from the modality. In the end, we have tried to offer an explanation of how the semantic change occurs and what the evolution of the semantic network of the (semi-)auxiliary deure was like.

Finally, we have shown that in the $16^{\text {th }} \mathrm{c}$. the situation changes dramatically: instances with future readings almost disappear. From our point of view, this kind of frustrated grammaticalization can be explained by the fact that the subjectification of the periphrasis does not go far enough: deure does not develop a subject-oriented future meaning, and this could stop its further evolution. In other words, modal meaning, transformed into a planning or an inference, is still present. Moreover, another fact must be taken into consideration, the evolution of the periphrasis $<$ haver $(a / d e)+\mathrm{INF}>$, which develops future meanings and occupies this space.

\section{Textual Corpus References}

(Agramont) d'Agramont, Jacme, <1348> Regiment de Preservació de la Pestilència, a cura de Joan Veny, Lleida, Universitat de Lleida i Enciclopèdia catalana, 1998. [Manuscript 1388]

(Carbonell, Cròniques) CARBOnell, Pere Miquel, Cròniques d'Espanya, <1495-1513> vol. 1, a cura d'Agustí Alcoberro, Barcelona, Barcino, 1997. [Manuscript 1547]

(Curial) Curial e Güelfa, <1435-1445> ed. d'Antoni Ferrando, Tolosa de Llenguadoc, Anacharsis Éditions, 2007. [Manuscript 1445-1458]

(Diàlegs) Alegre Urgell, Montserrat, Diàlegs de Sant Gregori. Retranscripció i estudi lingüistic de la versió catalana de 1340, <1250-1290> Universitat de Barcelona, tesi doctoral, 2004. [Manuscript 1340]

(Epistolari IIa) Rubio Vela, Agustí, Epistolari de la València medieval, v. II, <14121424> València / Barcelona, Institut Interuniversitari de Filologia Valenciana / Publicacions de l'Abadia de Montserrat, 1998.

(Fets) Llibre dels Fets del rei en Jaume, vol II, ed. de Jordi Bruguera, Barcelona, Barcino, 1991. [Manuscript del 1343]

(Furs) Corpus Informatitzat del Català Antic (CICA): Furs de València <1261-1271>, J. Torruella (dir.), Manel Pérez-Saldanya, Josep Martines and Vicent Martines. $<$ http://lexicon.uab.cat/cica>. 2010. [Manuscript de 1349]

(Homilies) Homilies d'Organyà <XIIb> a cura d' A.-J. Soberanas, A. Rossinyol, A. Puig, Barcelona, Barcino, 2001.

(Manual I) El primer manual de consells de la ciutat de València (1306-1326), <13061324> estudi i transcripció de Vicent Anyó Garcia, València, Ajuntament de València, 2001. 
(Marquès) Procés criminal contra Antònia Marquès $<1374-1377>$, Rabella i Ribas, Joan Anton (1998). Un matrimoni desavingut i un gat metzinat. Procés criminal barceloni del segle XIV. Barcelona: Institut d'Estudis Catalans.

(Medieval) Russell-Gebbett, Paul (1965). Mediaeval Catalan Linguistic Texts, Oxford, The Dolphin Book Co.LTD.

(Metge, Somni) Metge, Bernat. Lo somni. El sueño. <1398> edició de Julia Butinyà, Madrid, Centro de Lingüística Aplicada «Atenea», 2007. [Manuscript XV]

(MiS-AntText) Miret i Sans, Joaquim (1904). "El més antig text literari escrit en català precedit per una colecció de documents dels segles XIè, XIIè i XIIIè”. Revista de bibliografia catalana, VII, p. 5-47, 215-220.

(Pere IIIa) Epistolari de Pere III, <1344-1348> vol. I, a cura de Ramon Gubern, Barcelona, Barcino, 1955, p. 71-102.

(Safont, Dietari) Safont, Jaume, Dietari o Llibre de jornades (1411-1484) de Jaume Safont, ed. de Josep Maria Sans i Travé, Barcelona, Fundació Noguera, 1992. [Manuscript 1454-1484]

(Tirant) MARTORELl, Joanot, Tirant lo Blanch, $<1460>$ ed. d'Albert Hauf, València, Tirant lo Blanch, 2005. [Manuscript 1490]

(Vides) Vides de sants roselloneses, <1275-1299> v. II, edició a cura de Charlotte S. Maneikis Kniazzeh i Edward J. Neugaard, amb prefaci i aportacions de Joan Coromines, Barcelona, Fundació Salvador Vives Casajuana, 1977.

\section{References}

Bybee, Joan L.; Perkins, Revere; Pagliuca, William (1994). The Evolution of Grammar: Tense, Aspect, and Modality in the Languages of the World. Chicago / London: University of Chicago Press.

Cabanes, Vicent (1996). "Les perífrasis modals de necessitat-obligació i probabilitat en català. Seguiment diacrònic. Segles XIII-XX”. Caplletra 20: 129-164.

$C I C A=$ Corpus Informatitzat del Català Antic (CICA). Torruella, Joan (dir.): PérezSaldanya, Manuel; Martines, Josep; Martines, Vicent. <http://cica.cat $>$ [query 2009-2013].

$C I G C A=$ Martines, Josep; Martines, Vicent (dirs.): "Corpus Informatitzat de la Gramàtica del Català Antic" In Corpus Informatitzat Multilingüe de Textos Antics i Contemporanis [CIMTAC], Fuster, M. Àngels; Sánchez, Elena Sánchez; Ruiz, Ramon. Alacant, ISIC-IVITRA [query 2010-2013].

$D C V B=$ Alcover, Antoni Maria; Moll, Francesc de Borja (1928-1962): Diccionari Català-Valencià-Balear, 10 vol. Palma: Editorial Moll. [<http://dcvb.iecat.net $>$ ]

de Haan, Ferdinand (2006). "Typological approaches to modality". In Frawley, William (ed.). The Expression of Modality. Berlin / New York: Mouton de Gruyter.

Fleischman, Suzanne (1982). The Future in Thought and Language. Diachronic Evidence from Romance. Cambridge: Cambridge University Press.

Gavarró, Anna; Laca, Brenda (2002): "Les perífrasis temporals, aspectuals i modals". In Solà, Joan et al. (dir.), Gramàtica del català contemporani, vol. iii. Barcelona: Empúries, pp. 2663-2726.

Goossens, Louis (2000). "Patterns of meaning extension, 'parallel chaining', subjectification and modal shifts". In Barcelona, Antonio (ed.). Metaphor and Metonymy at 
the Crossroads. A Cognitive Perspective. Berlin / New York: Mouton de Gruyter, pp. 149-169.

Heine, Bernd; Claudi, Ulrike; Friederike Hünnemeyer (1991). Grammaticalization: A Conceptual Framework, 2 vol. Chicago: University of Chicago Press.

Herman, József (2001). El latín vulgar. Barcelona: Editorial Ariel.

Jensen, Frede (1986). The syntax of Medieval Occitan. Tübingen: Niemeyer.

Jensen, Frede (1990). Old French and Comparative Gallo-Romance Syntax. Tübingen: Niemeyer.

Traugott, Elizabeth Closs (2012). "Pragmatics and language change". In Allan, Keith; Jaszczolt, Kasia M. (ed.). The Cambridge Handbook of Pragmatics. Cambridge: Cambridge University Press, pp. 549-565.

Langacker, Ronald W. (1987). Foundations of Cognitive Linguistics, vol. I. Theorical Prerequisites. Stanford: Stanford University Press.

Langacker, Ronald W. (1991). Foundations of Cognitive Linguistics, vol. II. Descriptive Application. Stanford: Stanford University Press.

Langacker, Ronald W. (1999). Grammar and Conceptualization. Berlin / New York: Mounton de Gruyter.

Langacker, Ronald W. (2006). "Sujectification, Grammaticization, and Conceptual Archetypes". In Athanasiadou, Angeliki; Canakis, Costas; Cornillie Bert (eds.). Subjectification: Various Paths to Subjectivity. Berlin / New York: Mounton de Gruyter, pp. 17-40.

Martines, Josep (in press). “L'émergence des futurs épistémiques romans. L'exemple du catalan médiéval du XIIIème siècle", dins Laura Baranzini et al. (ed.), Le futur dans les langues romanes, Peter Lang.

Martines, Josep (this volume). "Semantic change and intersubjectification: the origin of reprise evidential conditional in Old Catalan".

Meyer-Lübke W. (1900). Grammarire des langues romanes. Trad. fr. de Auguste Doutrepont et Georges Doutrepont. 3 vol. Paris: H. Welter. [Reimpressió. 1974, Ginebra: Slatkine.]

Narrog, Heiko (2012). Modality, Subjectivity, and Semantic Change: A Cross-Linguistic Perspective. Oxford York: Oxford University Press.

Pelyvás, Péter (2000). "Metaphorical extension of may and must into the epistemic domain”. In Barcelona, Antonio (ed.). Metaphor and metonymy at the crossroads. Berlin / New York: Mouton de Gruyter, pp. 233-250.

Pelyvás, Péter (2001). "On the development of the category modal: a cognitive view. How changes in image-schematic structure led to the emergence of the grounding predication”. In Kocsány, Piroska; Molnár, Anna (eds.). Wort und (Kon)text. Frankfurt am Main: Peter Lang, pp. 103-130.

Pelyvás, Péter (2006). "Subjectification in (expressions of) epistemic modality and the development of the grounding predication". In Athanasiadou, Angeliki; Canakis, Costas; Cornillie, Bert (eds.). Subjectification: Various Paths to Subjectivity. Berlin / New York: Mounton de Gruyter, pp. 121-150.

Pérez-Saldanya, Manuel (1998). Del llatí al català: Morfosintaxi verbal històrica. València: Universitat de València.

Pérez-Saldanya, Manuel; Hualde, José Ignacio (2003). “On the origin and evolution of the Catalan periphrastic preterit”. In Claus, Claus D.; Wesch, Andreas (eds.). 
Verbalperiphrasen in den (ibero-)romanischen Sprachen. Hamburg: Helmut Buske Verlag, pp. 47-60.

Schmid, Beatrice (2008). «L'expressió de l'obligació al Llibre del Consolat de Mar i com és traduïda al castellà”. In Brandenberger, Tobias; Schmid, Beatrice; Winet, Monika (eds.). Traducción y estilística. Para el profesor Germán Colón en sus ochenta años (=ARBA 20). Basel: Universität Basel, pp. 19-40.

Segura, Carles (2012). "El passat perifràstic en català antic. Una revisió a partir d'estudi de corpus". eHumanista/IVITRA 2: 118-147.

Sentí, Andreu (2012). "Gramaticalització i subjectivització del verb modal haver (a/de) en català antic. Un estudi de corpus segons la gramàtica cognitiva." eHumanista/ IVITRA 2: 85-117.

Sentí, Andreu (2013). Gramaticalització i subjectivació de la modalitat en català antic. Un estudi de corpus de les perifrasis verbals $<$ deure $+\operatorname{Inf}>i<$ haver $(\mathrm{a} / \mathrm{de})+\operatorname{Inf}>$. $\mathrm{PhD}$ dissertation, University of Alacant (Josep Martines, director).

Sentí, Andreu (2015). "Subjectification and attenuation in the conceptual schema of the Catalan modal verb deure with evidential meaning". e-Humanista/IVITRA 8.

Sentí, Andreu; Antolí, Jordi (2014). "La inferència en l'aflorament dels valors evidencials en català antic.” Caplletra: Revista Internacional de Filologia, 56: 157-183.

Sentí, Andreu; Cornillie, Bert (in press), "The rise of the evidential readings of the Catalan periphrasis deure + infinitive." In Garachana; Montserrat; Pusch (eds.). From composite predicates to verbal periphrases in Romance languages. Amsterdam: John Benjamins

Squartini, Mario (2004). «Disentangling evidentiality and epistemic modality in romance». Lingua 114: 873-895.

$<$ http://dx.doi.org/10.1016/S0024-3841(03)00064-0>

Talmy, Leonard (1988). "Force dynamics in language and cognition". Cognitive Science 2: 49-100.

van der Auwera, Jan; Plungian, Vladimir. A. (1998). «Modality's semantic map», Linguistic Typology, 2, 79-124.

$<$ http://dx.doi.org/10.1515/lity.1998.2.1.79> 